\title{
Ecological responses of epilithic diatoms and aquatic macrophytes to fish farm pollution in a Spanish river
}

\author{
by
}

\author{
Julio A. Camargo \& Alma Jiménez
}

Departamento de Ecología, Facultad de Biología, Universidad de Alcalá, 28871 Alcalá de Henares (Madrid), Spain. julio.camargo@uah.es

\begin{abstract}
Camargo, J.A. \& Jiménez, A. 2007. Ecological responses of epilithic diatoms and aquatic macrophytes to fish farm pollution in a Spanish river. Anales Jard. Bot. Madrid 64(2): 213-219.
\end{abstract}

We examined the ecological responses of epilithic diatoms and aquatic macrophytes to organic pollution and nutrient enrichment caused by a trout farm effluent in the upper Tajuña River (Guadalajara, Spain). Four sampling sites were selected over the study area: one site (S-1) placed upstream from the trout farm was used as a reference station; sampling sites S-2, S-3 and S-4 were set, respectively, about 10, 100 and 1000 metres downriver of the trout farm outlet. The river bottom was mainly stony with cobbles and pebbles at S-1, S-3 and S-4, but at S-2 it was covered by a thick layer of organic sediment. Although some macrophyte species (Apium nodiflorum, Groenlandia densa) were either absent or fewer downstream of the farm, abundance (\% coverage) and diversity (number of species) for the aquatic macrophyte community as a whole increased. In contrast, epilithic diatoms were completely absent at S-2, and some species (Diploneis parma, Fragilaria ulna, Gomphonema angustatum, Nitzschia dissipata) were also absent at S-3 and S-4. Indeed, diatom diversity (number of species) was lower at S-3 and S-4 than at S-1. However, diatom abundance (cells/cm²) was higher at S-3 and S-4 than at S-1. Biological indices for diatoms (IBD, TDI) indicated a better water quality at S-1 than at S-3 and S-4, with a clear tendency to improve with distance from the fish farm. In contrast, biological indices of macrophytes (IM, IVAMG) indicated a similar water quality at S-1, S-3 and S-4, but with bad water quality at S-2. We conclude that epilithic diatoms may be more useful than aquatic macrophytes for biological monitoring of fish farm pollution in fluvial ecosystems. However, as historical and seasonal factors may be relevant to understanding the distribution, abundance and diversity of primary producers in running waters, further studies on long-term seasonal changes are needed to improve the use of macrophyte and diatom indices in assessing fish farm pollution.

Keywords: Spanish river, fish farm pollution, diatom and macrophyte responses.

\section{Resumen}

Camargo, J.A. \& Jiménez, A. 2007. Respuestas ecológicas de las diatomeas epilíticas y macrófitos acuáticos a la contaminación producida por una piscifactoría en un río español. Anales Jard. Bot. Madrid 64(2): 213-219 (en inglés).

En este trabajo examinamos las respuestas ecológicas de las diatomeas epilíticas y los macrófitos acuáticos a la contaminación orgánica y por nutrientes producida por el vertido de una piscifactoría situada en el tramo alto del río Tajuña (Guadalajara, España). Se seleccionaron cuatro puntos de muestreo a lo largo del área de estudio: uno aguas arriba de la piscifactoría empleado como punto control (S-1); los puntos S-2, S-3 y S-4 se ubicaron a 10,100 y $1000 \mathrm{~m}$ aguas abajo del punto de vertido, respectivamente. El lecho del río era principalmente rocoso, con guijarros y cantos rodados en S-1, S-3 y S-4, pero en S-2 estaba cubierto por una gruesa capa de sedimento orgánico. Pese a que algunas especies de macrófitos (Apium nodiflorum, Groenlandia densa) resultaron ausentes o vieron reducidas sus abundancias aguas abajo del vertido, la abundancia (\% covertura) y la diversidad (número de especies) del total de la comunidad de macrófitos acuáticos aumentó. En oposición a esto, las diatomeas epilíticas desaparecieron completamente en S-2, y algunas especies (Diploneis parma, Fragilaria ulna, Gomphonema angustatum, Nitzschia dissipata) también resultaron ausentes en S-3 y S-4. De hecho, la diversidad de diatomeas (número de especies) fue menor en S-3 y S-4 que en S-1. No obstante, la abundancia de diatomeas (células $/ \mathrm{cm}^{2}$ ) fue superior en S-3 y S-4 que en S-1. Los índices biológicos de diatomeas (IBD, TDI) indicaron una mejor calidad del agua en S-1 que en S-3 y S-4, con una tendencia clara a mejorar con la distancia a la piscifactoría. En contraste, los índices biológicos de macrófitos (IM, IVAM-G) indicaron una calidad del agua similar en S-1, S-3 y S-4, pero con una mala calidad del agua en S-2. ES concluido que las diatomeas epilíticas pueden ser más útiles que los macrofitos acuáticos para la monitorización biológica de la contaminación causada por las piscifactorías en los ecosistemas fluviales. No obstante, debido a que factores históricos y estacionales pueden ser relevantes para entender la distribución, abundancia y diversidad de los productores primarios en las aguas corrientes, estudios posteriores son necesarios para mejorar el uso de los índices de diatomeas y macrófitos para valorar la contaminación producida por las piscifactorías.

Palabras clave: río español, contaminación por piscifactoría, respuestas de diatomeas y macrófitas. 


\section{Introduction}

Natural changes in environmental conditions (e.g., flow, water temperature, dissolved oxygen, food resources) along the longitudinal profile of river systems exert direct control on the population dynamics of aquatic organisms, resulting in characteristic biological communities within this ecological succession (Whitton, 1975; Vannote \& al., 1980; Allan, 1995). Nevertheless, many human activities are polluting freshwater ecosystems, modifying the structure of aquatic communities and thereby disrupting the functional continuum of river systems (Camargo \& al., 2005). Indeed, anthropogenic pollution of freshwater ecosystems by the addition of organic matter and nutrients is an increasing phenomenon that affects many rivers worldwide (Camargo \& al., 2006; Szoszkiewicz \& al., 2006).

Inland fish farms may have major adverse effects on aquatic communities by modifying environmental conditions downstream from their outlets. According to Alabaster (1982) and Jones (1990), effluents of inland fish farms can contain three different types of pollutants: (1) pathogenic bacteria, viruses and parasites; (2) drugs and disinfectants for disease and parasite control; (3) residual food and faecal materials. The third type of pollutant appears to be most important in generating physicochemical and biological changes downstream from fish-farming outlets, primarily when artificial dry pellet diets are used (Alabaster, 1982; Jones, 1990).

Physicochemical alterations caused by residual food and faecal materials from fish farms often involve increases in inorganic nutrients (ammonium, nitrate, nitrite, phosphate) and suspended organic solids, a decrease in dissolved oxygen, and a settlement of suspended organic matter settling on the river bottom (Alabaster, 1982; Solbé, 1982; Kaspar \& al., 1988; Jones, 1990; Garcia-Ruiz \& Hall, 1996; Nordvarg \& Johansson, 2002). Biological alterations have been less studied and may depend on fish farm management, fish farm location along the river, and the particular ecological characteristics of each recipient river (Camargo, 1992). A significant increase in the abundance of primary producers is expected to occur as a consequence of nutrient enrichment (Carr \& Goulder, 1990; Murphy, 1998; Villanueva \& al., 2000; Daniel \& al., 2005).

The main purpose of this preliminary investigation was to examine the effects of fish farm effluent on the abundance and diversity (number of species) of epilithic diatoms and aquatic macrophytes in a Spanish river. We hypothesize that both abundance and diversity must increase as a consequence of nutrient enrichment. Furthermore, epilithic diatoms, aquatic macrophytes, benthic macroinvertebrates and fish are considered to be valuable indicators of the ecological status of running waters, and their monitoring is required by the European Water Framework Directive. However, recent studies (Hering \& al., 2006; Johnson \& al., 2006; Springe \& al., 2006; Thiébaut \& al., 2006) have shown that on the one hand macrophytes and fish and on the other diatoms and macroinvertebrates may be most appropriate for assessing ecological quality at river basin scale and on smaller spatial scales, respectively. In this sense, we also hypothesize that epilithic diatoms may be better indicators than aquatic macrophytes for assessing freshwater pollution caused by inland fish-farming effluents (i.e., point pollution sources).

\section{Study area and sampling sites}

Field studies were conducted in the Tajuña River (Guadalajara province, Central Spain), a small river within the Tajo (Tagus) River Basin. The watershed of this river is mainly underlain by calcareous rock, such as limestone, which induces the formation of hard waters with a high ionic content. The Tajuña River's natural flow pattern features maximum flows during winter and spring and minima in summer and fall.

The inland trout farm is about $13 \mathrm{~km}$ downriver of the river source, on the upper Tajuña River (Fig. 1). Current annual production is about 35 tons of rainbow trout (Onchorbynchus mykiss) reared on an artificial diet of dry pellets. Twenty years ago, annual production was about 75 tons (Camargo, 1992). Apparently, waste treatment has always involved simple settlement in a small sedimentation pond with no added chemicals.

For this research, four sampling sites were selected over the study area (Fig. 1). A sampling site (S-1) upstream of the trout farm was used as a reference station. Sampling sites S-2, S-3 and S-4 were about $10 \mathrm{~m}, 100 \mathrm{~m}$ and $1000 \mathrm{~m}$, respectively, downriver of the farm outlet. The riverbed was about $2-4 \mathrm{~m}$ wide through the study area. The river bottom was mainly stony, with cobbles and pebbles at $\mathrm{S}-1$ and $\mathrm{S}-3$, but at $\mathrm{S}-2$ it was covered by a thick layer of organic sediment.

\section{Materials and methods}

Physicochemical surveys were conducted in 2005 2006. Water velocity, temperature, conductivity, $\mathrm{pH}$, and dissolved oxygen were measured in situ accord- 
ing to standard methods (American Public Health Association, 1992; Wetzel \& Likens, 2000). Additionally, water samples for inorganic nutrient analysis were collected using clean polyethylene containers, chilled to $1-4^{\circ} \mathrm{C}$ in the dark and transported to the laboratory within 24 hours. In the laboratory, water samples were filtered through pre-rinsed $0.45 \mu \mathrm{m}$ cellulose acetate filters, and filtrates were used to determine concentrations of $\mathrm{PO}_{4}-\mathrm{P}, \mathrm{NH}_{4}-\mathrm{N}, \mathrm{NO}_{2}-\mathrm{N}$ and $\mathrm{NO}_{3}-\mathrm{N}$ by spectrophotometry (American Public Health Association, 1992; Wetzel \& Likens, 2000).

Epilithic diatoms were sampled in February 2006. At each sampling site, five submerged stones were removed from the riffle substratum, chilled to $1-4^{\circ} \mathrm{C}$ in the dark and transported to the laboratory within 24 hours. There, the clean surface of each stone was separately scraped using a hard-bristled brush, the scraped material being collected in a small plastic tray with $50 \mathrm{ml}$ of destilled water (Hauer \& Lamberti, 1996; Wetzel \& Likens, 2000). After homogenization, $5 \mathrm{ml}$ aliquot of each sample was cleaned by oxidation with hot $\mathrm{H}_{2} \mathrm{O}_{2}$ to remove the organic matter, leaving

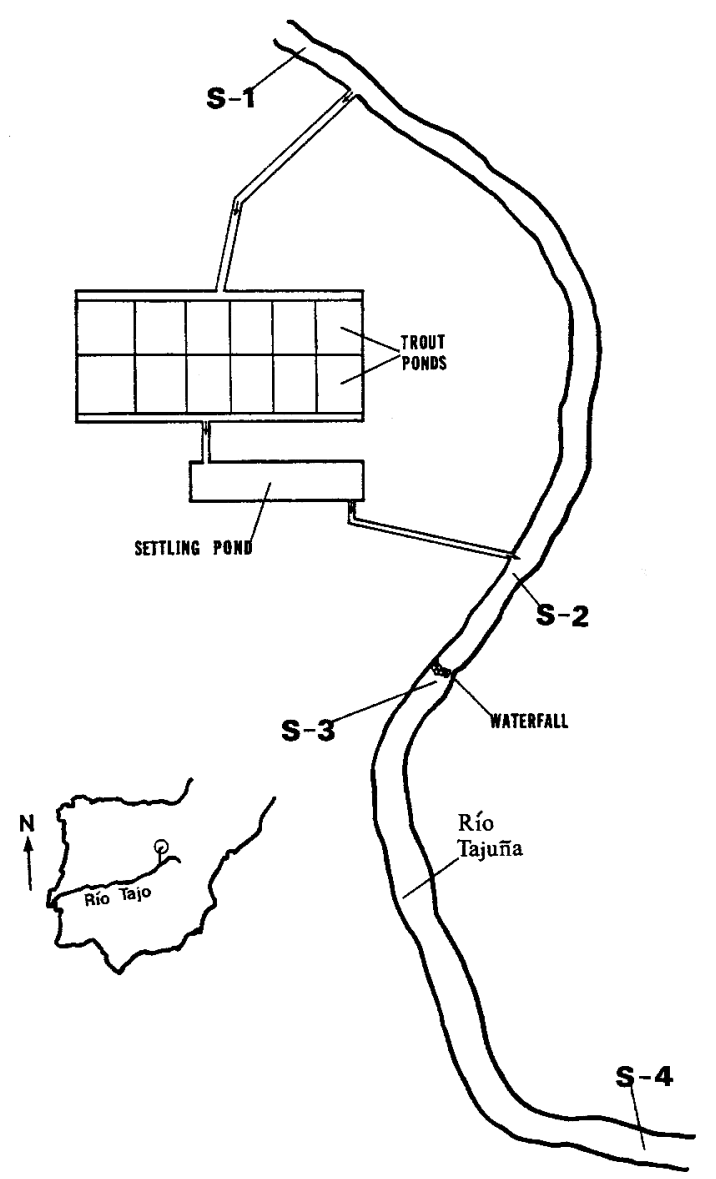

Fig. 1. Sampling site locations on the upper Tajuña River (Guadalajara, Central Spain). only the diatom valves. After centrifugation, permanent slides were mounted using Naphrax (r.i. = 1.74) and a drop $(1 \mu \mathrm{l})$ of cleaned samples. Diatom density was estimated by counting the number of diatoms with a light microscope at $400 \times$ magnification. Taxonomic identification to species level was conducted following the Süßwasserflora von Mitteleuropa (Krammer \& Lange-Bertalot, 1986, 1988, 1991a, b), using a light microscope at $1000 \times$ magnification. At least 400 diatom valves were identified on each slide. Stone surface areas (expressed in $\mathrm{cm}^{2}$ ) were estimated according to the "aluminium foil method" described in Hauer \& Lamberti (1996).

On the basis of species composition and abundance in the epilithic diatom community, we applied the Trophic Diatom Index (TDI; Kelly \& Whitton, 1995; Kelly, 1998) and the Biological Diatom Index (IBD; Descy \& Coste, 1991; Prygiel \& Coste, 2000) for assessing water quality. The TDI is based on the tolerance of a relatively small list of taxa (genera plus key indicator species) to nutrients (dissolved phosphorus, mainly), and takes values between 0 (very low nutrient concentration; excellent water quality) and 100 (very high nutrient concentration; very bad water quality). In our case, the TDI estimation was performed using all identified diatom taxa. The IBD also is based on the tolerance of a relatively small list of about 210 diatom species to nutrients (dissolved phosphorus, mainly), and takes values between 1 (very high nutrient concentration; very bad water quality) and 20 (very low nutrient concentration; excellent water quality). When no diatom is found in the samples, a value of zero is given to the IBD. In our case, because the IBD is more specific than the TDI, some diatom species, such as Amphora commutata, Cymbella perpusilla, Navicula cryptofallas, Navicula similis and Stauroneis anceps, could not be considered for estimating the IBD index.

Aquatic macrophytes were sampled in June-July 2006. An area of about $100 \mathrm{~m}^{2}$ was selected at each sampling site, and coverage percentage was estimated for each taxon and for the whole community. In addition, macrophyte samples were collected, chilled to 1$4^{\circ} \mathrm{C}$ in the dark, and transported to the laboratory for better taxonomic identification to species level following Cirujano \& Medina (2002) and Casas \& al. (2006).

On the basis of species composition and species abundance in the community of aquatic macrophytes, we applied the Index of Macrophytes (IM; Suárez \& al., 2005) and the Macroscopic Aquatic Vegetation Index to genera (IVAM-G; Moreno \& al., 2006) in order to assess water quality. The IM is based on the dif- 
ferential sensitivity of a relatively small list of taxa (general groups of algae, bryophytes, pteridophytes and phanerogams, plus key indicator genera) to organic pollution and nutrient enrichment, taking values between $<5$ (high pollution level; bad water quality) and $>30$ (low pollution level; excellent water quality). The IVAM-G is based on the differential sensitivity of a more comprehensive list of taxa ( 50 genera of algae, pteridophytes and phanerogams, plus general groups of bryophytes) to organic pollution and nutrient enrichment, taking values between $<2.0$ (high pollution level; bad water quality) and $>5.7$ (low pollution level; excellent water quality). In our case, the following macrophyte species could not be considered for the estimation of both IM and IVAM-G indices: Groenlandia densa, Phragmites australis and Typha latifolia.

\section{Results and discussion}

Mean values of water physicochemical parameters at each sampling site are presented in Table 1 . Differences between the reference site (S-1) and downstream polluted sites (S-2, S-3 and S-4) were significant $(P<0.01$; t-test $)$ for dissolved oxygen, nitrate, nitrite, ammonium and phosphate. Whereas the concentration of dissolved oxygen decreased, particularly at S-2, the concentration of dissolved inorganic nutrients increased downstream from the trout farm outlet. Mean values of inorganic nutrients clearly indicate a downstream process of nutrient enrichment as a consequence of the farm's deficient waste-water treatment system. Similar physicochemical changes have already been observed for other rivers receiving fish farm effluents (Alabaster, 1982; Solbé, 1982; Carr \& Goulder, 1990; Jones, 1990; Camargo, 1994; GarciaRuiz \& Hall, 1996).

As a consequence of the acute process of nutrient enrichment, aquatic macrophytes and epilithic diatom abundances tended to increase downstream ( Ta-

Table 1. Mean values of water physicochemical parameters at sampling sites.

\begin{tabular}{|l|c|c|c|c|}
\hline & S-1 & S-2 & S-3 & S-4 \\
\hline Water velocity $(\mathrm{cm} / \mathrm{s})$ & 29.4 & 18.5 & 26.7 & 26.1 \\
Water temperature $\left({ }^{\circ} \mathrm{C}\right)$ & 9.5 & 8.1 & 8.0 & 7.9 \\
$\mathrm{pH}$ & 8.4 & 7.9 & 8.0 & 8.1 \\
Conductivity $(\mu \mathrm{S} / \mathrm{cm})$ & 627 & 650 & 670 & 689 \\
Dissolved oxygen $\left(\mathrm{mg} \mathrm{O}_{2} / \mathrm{l}\right)$ & 9.7 & 4.6 & 5.8 & 7.6 \\
Phosphate $\left(\mathrm{mg} \mathrm{PO}_{4}-\mathrm{P} / \mathrm{l}\right)$ & 0.05 & 0.42 & 0.46 & 0.39 \\
Nitrate $\left(\mathrm{mg} \mathrm{NO}_{3}-\mathrm{N} / \mathrm{l}^{\circ}\right)$ & 2.5 & 3.3 & 3.2 & 3.9 \\
Nitrite $\left.\left(\mathrm{mg} \mathrm{NO}_{2}-\mathrm{N} / l\right)\right)$ & 0.02 & 0.05 & 0.06 & 0.11 \\
Ammonium $\left(\mathrm{mg} \mathrm{NH}_{4}-\mathrm{N} / \mathrm{l}\right)$ & 0.06 & 0.77 & 0.65 & 0.37 \\
\hline
\end{tabular}

bles 2 and 3). The total coverage for the whole community of aquatic macrophytes increased from $52.8 \%$ at S-1 to $70.6 \%$ at S-3 and $81.5 \%$ at S-4 (Table 2). Similarly, total density for the whole community of epilithic diatoms increased significantly $(P<0.01$; $t$ test) from $10366 \mathrm{cells} / \mathrm{cm}^{2}$ at S-1 to $109120 \mathrm{cells} / \mathrm{cm}^{2}$ at S-3 and 27956 cells $/ \mathrm{cm}^{2}$ at S-4 (Table 3). Increases in the abundance of primary producers have already been observed in other polluted rivers experiencing significant nutrient enrichment (Villanueva \& al., 2000; Schneider \& Melzer, 2003; Camargo \& al., 2005; Daniel \& al., 2005; Leira \& Sabater, 2005; Moreno \& al., 2006).

Despite their increases in abundance at S-3 and S-4 with regard to $S-1$, there was a clear difference between the whole community of aquatic macrophytes and the whole community of epilithic diatoms. Whereas the former increased in abundance and diversity (from 6 species at $S-1$ to 7 species at $S-3$ and 8 species at S-4), the latter increased, abundance but decreased its diversity (from 20 species at S-1 to 13 species at S-3 and 19 species at $\mathrm{S}-4)$. In this respect it is interesting to note that Daniel \& al. (2005), studying the effects of fish-farming pollution on aquatic macrophytes in two salmon rivers located in Brittany (France), found that both macrophyte abundance and diversity usually increased downstream from fish farms.

On the other hand, at S-2, the absence of epilithic diatoms and the decrease in the abundance and diversity of submerged macrophytes (Tables 2 and 3 ) were

Table 2. Species composition and species abundance (coverage $\%$ ) of aquatic macrophytes at sampling sites. Values for total coverage (for whole community) and macrophyte indices (IM, IVAM-G) are also given.

\begin{tabular}{|l|r|r|r|r|}
\hline & S-1 & S-2 & S-3 & S-4 \\
\hline Apium nodiflorum (L.) & 43.5 & 0.0 & 10.6 & 7.2 \\
Cladophora sp. & 0.0 & 14.6 & 17.2 & 18.6 \\
Groenlandia densa (L.) & 17.0 & 0.0 & 0.0 & 0.0 \\
Lemna minor L. & 10.5 & 18.4 & 16.4 & 11.3 \\
Leptodictyum & 7.5 & 0.0 & 11.5 & 20.5 \\
$\quad$ riparium (Hedw.) & & & & \\
Phragmites australis (Cav.) & 9.2 & 41.3 & 23.7 & 15.8 \\
Ranunculus peltatus Schr. & 0.0 & 0.0 & 8.6 & 5.9 \\
Typha latifolia L. & 12.3 & 25.7 & 12.0 & 4.5 \\
Verónica & & & & \\
$\quad$ anagallis-aquatica L. & 0.0 & 0.0 & 0.0 & 16.2 \\
Total coverage for & & & & \\
$\quad$ whole community (\%) & 52.8 & 33.2 & 70.6 & 81.5 \\
Diversity (number & & & & \\
$\quad$ of species) & 6 & 4 & 7 & 8 \\
IM & 16 & 4 & 25 & 29 \\
IVAM-G & 4.4 & 2.0 & 4.5 & 4.4 \\
\hline
\end{tabular}


probably due to the strong sedimentation of organic matter on the river bottom, which produced a thick layer of organic sediment. Submerged macrophytes and epilithic diatoms appear to be very sensitive to the sedimentation of suspended solids (Descy \& Coste, 1991; Kelly \& Whitton, 1995; Kelly, 1998; Prygiel \& Coste, 2000; Wetzel, 2001; Cirujano \& Medina, 2002; Schneider \& Melzer, 2003; Gosselain \& al., 2005; Suárez \& al., 2005; Moreno \& al., 2006; Szoszkiewicz $\&$ al., 2006). Furthermore, some epilithic diatoms (Cymbella affinis, Diploneis parma, Fragilaria ulna, Gomphonema angustatum, Navicula similis, Nitzschia dissipata) and submerged macrophytes (Apium nodiflorum, Groenlandia densa) were either absent or less abundant at S-3 and S-4 with regard to S-1 (Tables 2 and 3). These diatoms and macrophytes usually grow better in unpolluted rivers and streams with naturally mesotrophic waters (Prygiel \& Coste, 2000; Cirujano \& Medina, 2002; Schneider \& Melzer, 2003; Gosselain \& al., 2005; Leira \& Sabater, 2005; Szoszkiewicz $\&$ al., 2006).

Conversely, other epilithic diatoms (Achnanthes lanceolata, Achnanthes minutissima, Amphora commutata, Amphora ovalis, Navicula capitatoradiata,
Navicula minima, Navicula recens, Navicula tripunctata, Nitzschia fonticola, Nitzschia sociabilis, Stauroneis anceps) and aquatic macrophytes (Cladophora sp., Phragmites australis, Ranunculus peltatus, Typha latifolia, Veronica anagallis-aquatica) clearly increased their abundances at S-3 and S-4 with regard to S-1 (Tables 2 and 3). These diatoms and macrophytes are relatively tolerant of organic pollution and nutrient enrichment, growing well in eutrophic waters and often forming dense stands (Prygiel \& Coste, 2000; Cirujano \& Medina, 2002; Schneider \& Melzer, 2003; Gosselain \& al., 2005; Leira \& Sabater, 2005; Szoszkiewicz \& al., 2006). However, because aquatic mosses are in general considered to be indicators of good water quality (Suárez \& al., 2005; Moreno \& al., 2006), it is surprising that Leptodictyum riparium also increased its abundance at S-3 and S-4 with regard to S-1 (Table 2). In this respect, Szoszkiewicz \& al. (2006) have showed that some aquatic mosses may be tolerant to organic pollution and nutrient enrichment, although they did not found any specific indicator value for $L$. riparium.

Values of IM, IVAM-G, IBD and TDI indices are presented in Tables 2 and 3. The spatial variation of

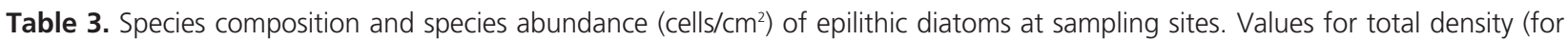
whole community) and of diatom indices (IBD, TDI) are also given.

\begin{tabular}{|c|c|c|c|c|}
\hline & S-1 & S-2 & S-3 & S-4 \\
\hline Achnanthes biasolettiana Grun. & 845 & 0 & 0 & 1248 \\
\hline Achnanhtes lanceolata (Breb.) & 372 & 0 & 3428 & 772 \\
\hline Achnanthes minutissima Kütz. & 1932 & 0 & 25127 & 4518 \\
\hline Amphora commutata Grun. & 429 & 0 & 20549 & 3965 \\
\hline Amphora ovalis Kütz. & 753 & 0 & 20414 & 1220 \\
\hline Cocconeis placentula Ehrenb. & 1125 & 0 & 0 & 2864 \\
\hline Cymbella affinis Kütz. & 810 & 0 & 0 & 89 \\
\hline Cymbella perpusilla Clev.-Eul. & 0 & 0 & 0 & 51 \\
\hline Cymbella silesiaca Bleis. & 183 & 0 & 0 & 596 \\
\hline Diploneis parma Cleve & 487 & 0 & 0 & 0 \\
\hline Epithemia adnata (Kütz.) & 1148 & 0 & 4420 & 603 \\
\hline Fragilaria capuchina Desm. & 0 & 0 & 0 & 114 \\
\hline Fragilaria ulna Nitzs. & 504 & 0 & 0 & 0 \\
\hline Gomphonema angustatum (Kütz.) & 439 & 0 & 0 & 0 \\
\hline Gomphonema parvulum (Kütz.) & 315 & 0 & 2843 & 0 \\
\hline Navicula capitatoradiata Germ. & 256 & 0 & 3637 & 1566 \\
\hline Navicula cryptofallax Lan.-Bert.\&Hofm. & 227 & 0 & 0 & 573 \\
\hline Navicula minima Grun. & 0 & 0 & 1274 & 0 \\
\hline Navicula recens Lan.-Bert. & 0 & 0 & 9372 & 4384 \\
\hline Navicula similis Krass. & 154 & 0 & 0 & 72 \\
\hline Navicula tripunctata Mull. & 282 & 0 & 7585 & 485 \\
\hline Nitzschia dissipata (Kütz.) & 31 & 0 & 0 & 0 \\
\hline Nitzschia fonticola Grun. & 24 & 0 & 2100 & 915 \\
\hline Nitzschia sociabilis Huso. & 50 & 0 & 6386 & 2604 \\
\hline Stauroneis anceps Ehrenb. & 0 & 0 & 1984 & 1317 \\
\hline Total density for whole community (cells/cm²) & 10366 & 0 & 109120 & 27956 \\
\hline Diversity (number of species) & 20 & 0 & 13 & 19 \\
\hline IBD & 15.1 & 0 & 10.8 & 14.3 \\
\hline TDI & 38.7 & - & 64.6 & 56.0 \\
\hline
\end{tabular}


these biological indices clearly indicates a marked decrease in freshwater quality just below the trout-farming effluent (S-2), with a clear tendency to increase and recover freshwater quality with distance to the fish farm (S-3 and S-4). However, this pattern of change in water quality was much better recorded by diatom indices (TDI, IBD) than by macrophyte indices (IM, IVAM-G), since nutrient concentrations were significantly higher at S-3 and S-4 than at S-1 (Table 1). It should be evident that this better performance of diatom indices was due to the decreased diversity (number of species) that the community of epilithic diatoms exhibited downstream of the trout farm (at S-2, S-3 and S-4; Table 3), whereas the community of aquatic macrophytes experienced a decrease in diversity at $\mathrm{S}-2$, but increases in diversity at S-3 and S-4 (Table 2).

\section{Conclusions}

We conclude that epilithic diatoms are more useful than aquatic macrophytes for the biological monitoring of fish farm pollution (i.e., point pollution sources) in fluvial ecosystems, since their higher diversity and benthic condition permit diatoms to respond better to a broad spectrum of stress affecting the freshwater habitat, at least locally. In this sense we agree with other authors (Hering \& al., 2006; Johnson \& al., 2006; Springe \& al., 2006; Thiébaut \& al., 2006) in that aquatic macrophytes may be most appropriate for assessing ecological quality at the river basin scale, whereas epilithic diatoms may be most appropriate for assessing ecological quality at smaller (local) spatial scales. Nevertheless, because historical and seasonal factors may be relevant to understanding the distribution, abundance and diversity of primary producers in running waters (Allan, 1995; Wetzel, 2001; Preston \& al., 2003), further studies on long-term seasonal changes are needed to improve the use of macrophyte and diatom indices in assessing fish farm pollution.

\section{Acknowledgements}

We are very grateful to Cristina Gonzalo for her help with the physicochemical analyses. We also are very grateful to Dr. Santos Cirujano and Katia Cezón for their assistance during the taxonomic identification of aquatic macrophytes. We also wish to express our sincere gratitude to two anonymous reviewers for their valuable comments and suggestions. Funds for this research were provided through the collaboration agreement between "IberCaja (Obra Social y Cultural)" and "Universidad de Alcalá". This study was completed and the manuscript written while Dr. Julio A. Camargo was spent a sabbatical period at the "Real Jardín Botánico (CSIC)" at Madrid".

\section{References}

Alabaster, J.S. 1982. Surveys of fish farm effluents in some EIFAC countries. EIFAC Technical Paper 41: 5-20.

Allan, J.D. 1995. Stream ecology: structure and function of running waters. Chapman \& Hall, London.

American Public Health Association. 1992. Standard methods for the examination of water and wastewater, $18^{\text {th }}$ edition. APHAAWWA-WPCF, Washington, DC.

Camargo, J.A. 1992. Temporal and spatial variations in dominance, diversity and biotic indices along a limestone stream receiving a trout farm effluent. Water Air Soil Pollut. 63:343-359.

Camargo, J.A. 1994. The importance of biological monitoring for the ecological risk assessment of freshwater pollution: a case study. Environ. Inter. 20: 229-238.

Camargo, J.A., Alonso, A. \& de la Puente, M. 2005. Eutrophication downstream from small reservoirs in mountain rivers of Central Spain. Water Res. 39: 3376-3384.

Camargo, J.A. \& Alonso, A. 2006. Ecological and toxicological effects of inorganic nitrogen pollution in aquatic ecosystems: a global assessment. Environ. Inter. 32: 831-849.

Carr, O.J. \& Goulder, R. 1990. Fish farm effluents in rivers: effects on inorganic nutrients, algae and the macrophyte Ranunculus penicillatus. Water Res. 24: 639-647.

Casas, C., Brugués, M., Cros, R.M. \& Sérgio, C. 2006. Handbook of mosses of the Iberian Peninsula and the Balearic Islands. Institut d'Estudis Catalans, Barcelona.

Cirujano, S. \& Medina, L. 2002. Plantas acuáticas de las lagunas y bumedales de Castilla-La Mancha. Real Jardín Botánico (CSIC) y Junta de Comunidades Castilla-La Mancha, Madrid.

Daniel, H., Bernez, I., Haury, J. \& Le Coeur, D. 2005. The ability of aquatic macrophytes to assess fish farm pollution in two salmon rivers. Hydrobiologia 551: 183-191.

Descy, J.P. \& Coste, M. 1991. A test of methods for assessing water quality based on diatoms. Verhand. Internat. Verein. Limnol. 24: 2112-2116.

Garcia-Ruiz, R. \& Hall, G.H. 1996. Phosphorus fractionation and mobility in the food and faeces of hatchery reared rainbow trout (Onchorhynchus mykiss). Aquaculture 145: 183-193.

Gosselain, V., Coste, M., Campeau, S., Ector, L., Fauville, C., Delmas, F., Knoflacher, M., Licursi, M., Rimet, F., Tison, J., Tudesque, L. \& Descy, J.-P. 2005. A large-scale stream benthic diatom database. Hydrobiologia 542: 151-163.

Hauer, F.R. \& Lamberti, G.A. (eds.). 1996. Methods in stream ecology. Academic Press, San Diego.

Hering, D., Johnson, R.K. \& Buffagni, A. 2006. Linking organism groups: major results and conclusions from the STAR project. Hydrobiologia 566: 109-113.

Johnson, R.K., Hering, D., Furse, M.T. \& Verdonschot, P.F.M. 2006. Indicators of ecological change: comparison of the early response of four organism groups to stress gradients. Hydrobiologia 566: 139-152.

Jones, J.G. 1990. Pollution from fish farms. J. Inst. Water Environ. Man. 4: 14-18.

Kaspar, H.F., Grahame, H.H. \& Holland, A.J. 1988. Effects of sea cage salmon farming on sediment nitrification and dissimilatory nitrate reductions. Aquaculture 70: 333-344.

Kelly, M.G. 1998. Use of the Trophic Diatom Index to monitor eutrophication in rivers. Water Res. 32: 236-242.

Kelly, M.G.\& Whitton, B.A. 1995. The Trophic Diatom Index: a new index for monitoring eutrophication in rivers. J. Appl. Phycol. 7: 433-444.

Krammer, K. \& Lange-Bertalot, H. 1986. Bacillariophyceae. 1. In: Ettl, H., Gerloff, J., Heynig, H. \& Mollenhauer, D. (eds.), Süßwasserflora von Mitteleuropa. Gustav Fischer Verlag, Stuttgart, New York. 
Krammer, K. \& Lange-Bertalot, H. 1988. Bacillariophyceae. 2. In: Ettl, H., Gerloff, J., Heynig, H. \& Mollenhauer, D. (eds.), Sü?wasserflora von Mitteleuropa. Gustav Fischer Verlag, Stuttgart, New York.

Krammer, K. \& Lange-Bertalot, H. 1991a. Bacillariophyceae. 3. In: Ettl, H., Gerloff, J., Heynig, H. \& Mollenhauer, D. (eds.), Süßwasserflora von Mitteleuropa. Gustav Fischer Verlag, Stuttgart, New York.

Krammer, K. \& Lange-Bertalot, H. 1991b. Bacillariophyceae. 4. In: Ettl, H., Gerloff, J., Heynig, H. \& Mollenhauer, D. (eds.), Süßwasserflora von Mitteleuropa. Gustav Fischer Verlag, Stuttgart, New York.

Leira, M. \& Sabater, S. 2005. Diatom assemblages distribution in Catalan rivers, NE Spain, in relation to chemical and physiographical factors. Water Res. 39: 73-82.

Moreno, J.L., Navarro, C. \& de las Heras, J. 2006. Propuesta de un índice de vegetación acuática (IVAM) para la evaluación del estado trófico de los ríos de Castilla-La Mancha: comparación con otros índices bióticos. Limnetica 25: 821-838.

Murphy, M.L. 1998. Primary production. In: Naiman, R.J. \& Bilby, R.E. (eds.), River ecology and management. Lessons from the Pacific Coastal Ecoregion. Springer Verlag, New York: 144-68.

Nordvarg, L. \& Johansson, T. 2002. The effects of fish farm effluents on the waters quality in the Aland archipelago, Baltic Sea. Aquac. Eng. 25: 253-279.

Preston, C.D., Sheail, J., Armitage, P. \& Davy-Bowker, J. 2003. The long-term impact of urbanisation on aquatic plants: Cambridge and the River Cam. Science Total Environ. 314-316: 67-87.

Prygiel, J. \& Coste, M. 2000. Guide méthodologique pour la mise en oeuvre de l'Indice Biologique Diatomées (IBD). Norme Française T 90-354, France.

Schneider, S. \& Melzer, A. 2003. The trophic index of macrophytes (TIM): a new tool for indicating the trophic state of running waters. Internat. Rev. Hydrobiol. 88: 49-67.
Solbé, J.F. 1982. Fish farm effluents: a United Kingdom survey. EIFAC Technical Paper 41: 29-55.

Springe, G., Sandin, L., Briede, A. \& Skuja, A. 2006. Biological quality metrics: their variability and appropriate scale for assessing streams. Hydrobiologia 566: 153-172.

Suárez, M.L., Mellado, A., Sánchez-Montoya, M.M. \& VidalAbarca, M.R. 2005. Propuesta de un índice de macrófitos (IM) para evaluar la calidad ecológica de los ríos de la cuenca del Segura. Limnetica 24: 305-318.

Szoszkiewicz, K., Ferreira, T., Korte, T., Baattrup-Pedersen, A., Davy-Bowker J. \& O'Hare, M. 2006. European river plant communities: the importance of organic pollution and the usefulness of existing macrophyte metrics. Hydrobiologia 566: 211234.

Thiébaut, G., Tixier, G., Guérold, F. \& Muller, S. 2006. Comparison of different biological indices for the assessment of river quality: application to the upper river Moselle (France). Hydrobiologia 570: 159-164.

Vannote, R.L., Minshall, G.W., Cummins, K.W., Sedell, J.R. \& Cushing, C.E. 1980. The river continuum concept. Can. J. Fish. Aquat. Sci. 37: 130-137.

Villanueva, V.D., Queimalinos, C., Modenutti, B. \& Ayala, J. 2000. Effects of fish farm effluents on the periphyton of an Andean stream. Arch. Fish. Mar. Res. 48: 283-294.

Wetzel, R.G. 2001. Limnology: lake and rivers ecosystems, $3^{\text {rd }}$ edition. Academic Press, San Diego.

Wetzel, R.G. \& Likens, G.E. 2000. Limnological analyses, $3^{\text {rd }}$ edition. Springer, New York.

Whitton, B.A. (ed.). 1975. River ecology. Blackwell Scientific Publications, Oxford.

Associate Editor: A. Flores Received: 14-II-2007 Accepted: 21-V-2007 